\title{
The Patients' Opinion of the Health Visitor Efficiency
}

1 Božica Zubec

2 Jelena Lučan

1 Health Center Sisak, Sisak, Croatia

2 Viktorovac High School, Sisak, Croatia

Article received: 28.08.2019.

Article accepted: 11.02 .2020$.

DOI: $10.24141 / 2 / 4 / 1 / 4$

Author for correspondence:

Jelena Lučan

Viktorovac High School

Aleja narodnih heroja 1, Sisak

E-mail: jjokic1@gmail.com

Keywords: health visiting service, users' contentment

\section{Abstract}

Aim. To test the users' contentment with the health visiting service, to see if the users are getting enough information about their health condition, to see if the users feel they are being frequently visited by the health visitor and to check whether something needs to be changed in the health visiting service work.

Methods. The research was carried out as a term study. 128 users of the health visiting service of Health Centre Sisak participated in a 25-question survey. The answers were defined by the Likert scale.

Results. 82 respondents (65\%) believe that the service is exceptionally organised and 95 of them (75\%) are getting all the necessary information about their health condition. 89 respondents (71\%) are visited by the service once a month. Some of the suggestions on how to improve the service are the following: more frequent visits, introduction of the afternoon shift for the employed respondents and larger number of health visitors which would prolong their stay at the respondent's home.

Conclusion. The users of the health visitor service have positive attitude towards the service and they feel they are getting enough information about their health condition. 


\section{Introduction}

The home care health service became an independent activity after the Homeland War, when it was separated from the general/family medicine teams, but due to its focus on curative activities, preventive work is abandoned, which should be the base of the home care activity (1). The field of activity of the home care nurse includes the development of a health care plan, implementation, evaluation of the procedures performed, preventive work in cooperation with general practice/family physicians, gynecologists, pediatricians, employees of health centers, as well as those in lease, social institutions, schools, home health care institutions, users themselves and their families, all based on their own observations and estimates (2). Home care nursing services are fully covered by the Croatian Health Insurance Fund, and all insured persons are entitled to free use when necessary (3). The home care nurse educational and health care activity takes place in the family and the community within the primary health care and includes the entire population (4). The name of the home care nurse (patronage) has its source in the Latin word patronus, which means caretaker, patroness, advocate, defender (5). The home care nurse's activity is focused on home visits to the user. During home visits, the nurse collects anamnestic data, performs physical assessment, observes, provides advice and guidance. The home care nurse also participates in the implementation of national early cancer screening program, and plays an important role in raising the response, motivating and educating individuals to participate in the programs (6). When a patient leaves the hospital and completes hospital treatment, the head nurse sends a home care nurse in charge of the area of residence in which the patient is living and a hospital discharge letter describing the need for continuing care in the home (7). The basic measures in home health care are: the protection of pregnant women, postpartum women and newborns, infants and young children, the protection of the chronically ill children and adults, the elderly, and protection of persons with disabilities $(8,9)$. The home care nurse is required to explain, to the home care user, the care and the procedures the home care nurse will perform. Home health care is a primary health care activity carried out independent-
Iy by nurses with a high school diploma and a work permit from the Croatian Chamber of Nurses employed at Home Health Care Institutions or who are self-employed. Nursing services are provided by the nurse at the request, in agreement with and under the supervision of a selected physician, and under the supervision of the home care nurse (10). Patients today strive to be active participants in their health care - from planning to realization, and they want their family to be involved in this process, they want to be members of the team providing health care, to participate in the work of the team (11).

\section{Aim}

To examine the attitudes of home care users; to investigate whether the users receive sufficient information from the home care nurse about their health status; whether they think that the home care nurse frequently visits them; to examine the opinions of the users about what they would change in the home care activity. In addition, the researchers sought to examine whether there are differences in attitudes with regard to rural and urban areas, gender, age and education level of users.

\section{Hypotheses}

Hypothesis 1. Beneficiaries have a positive attitude towards the health care service.

Hypothesis 2. Beneficiaries receive sufficient information from the home care nurse about their health status. 


\section{Methods}

The survey was conducted on a total of 128 users of the Sisak Health Care Center's Home Care Service in the period from May 1 - May 31, 2019. Prior to conducting the research, the permission of the Ethics Committee of the Sisak Health Center and the written consent of each respondent were obtained. All beneficiaries use home health care services - in their own apartment/home or visit the home care in infirmary. Users in different areas covered by the Sisak Health Center, rural and urban areas, were surveyed. The survey was conducted using a questionnaire. The questions in the survey were designed by Božica Zubec. The first part of the questionnaire covers general data on the characteristics of the respondents, gender, age, place of residence, level of education, employment, visits of the home care nurse and/or home care professional, and the provision of home care services. The second part of the questionnaire examines the attitudes of home health care users. In twenty-five questions, users choose the figure that best reflects their views using a Likert scale (1=strongly disagree, 2 =disagree, 3 =can't decide, $4=$ agree, $5=$ fully agree). The third part of the questionnaire examines how the user would report a specific problem related to nursing care, where the user chooses one of the offered answers. The fourth part of the questionnaire is filled in by the users by writing in a descriptive way if they wish to change something in the functioning of the home care service, which they believe would improve the work of the home care nurse.

\section{Statistics}

Categorical data are represented using absolute and relative frequencies. The normality of the distribution of numerical variables was tested by the Shapiro-Wilk test. Numerical data are described by the median and interquartile ranges due to distributions that do not follow the normal distribution. Differences between normally distributed numerical variables between two independent groups were tested by Mann Whitney's $U$ test and between three independent groups by the Kruskal Wallis test. The significance level was set to Alpha $=0.05$. The statistical program MedCalc
Statistical Software version 18.11.3 (MedCalc Software bvba, Ostend, Belgium; https://www.medcalc. org; 2019) was used for statistical analysis.

\section{Results}

The study was conducted on 128 subjects, of which $29(22.7 \%)$ were men and $99(77.3 \%)$ were women. The average (median) age of the respondents is 69 years, with interquartile ranges from 55 to 77 years, ranging from a minimum of 23 to a maximum of 89 years. The majority of the respondents, 61 (47.7\%), are aged 61 to 80 . There are $65(50.8 \%)$ respondents from rural areas, and, according to level of education, 58 (45.3\%) have high school education. 27 (21.1\%) respondents are employed. In addition to the home care nurse $33(25.8 \%)$ respondents are also visited by a home care professional. The majority of the respondents, 120 (93.8\%), have contact with a home care nurse at their home/apartment. The median number of home care nurse visits is 12 months (interquartile range from 4 to 36 months) ranging from one month to 168 months (Table 1 ).

$82(65 \%)$ of the respondents agree that the organization of the home care service is excellent, and 47 $(40 \%)$ are not sure if there is an accessible book of complaints and praise. 95 (75\%) of the respondents state that they receive most of the necessary information about their health status from the home care nurse. The nurse visits most of the respondents, $89(71 \%)$, once a month, while $5(4 \%)$ disagree or strongly disagree with the statement that with information on their health status, the home care nurse provides information on the exercise of their rights.

For $93(73 \%)$ respondents, the home care nurse will inform their physician of their health problems. 22 $(18 \%)$ of the respondents agree or fully agree with the statement that some of their home care nurses' advice contradicts the advice of other health professionals (e.g. general practice physician). 101 (82\%) of the respondents fully agree that the visit of the home care nurse is beneficial. 86 (68\%) of the respondents fully agree with the statement that from the nurse they receive a lot of new information regarding their health status, and $26(21 \%)$ of the respondents 
state that the visits should be more frequent, while $36(30 \%)$ do not agree or strongly disagree with this claim (Table 2).

Table 1. Basic characteristics of the respondents

Number

(\%) of

respondents

\section{Gender}

Men

Women

Age groups

up to 40

$18(14.1)$

$41-60$

$18(14.1)$

$61-80$

$61(47.7)$

81 and more

$13(10.2)$

Unanswered

18 (14.1)

Place of residence

Village

65 (50.8)

Town

60 (46.9)

Unanswered

$3(2.3)$

Level of education

Elementary school

51 (39.8)

High school education

$58(45.3)$

Baccalaureus

$12(9.4)$

University education/Masters

4 (3.1)

Unanswered

$3(2.3)$

Employment

Yes

27 (21.1)

No

$95(74.2)$

Unanswered

$6(4.7)$

In addition to home care nurse I am

visited by home care professional

Yes

$33(25.8)$

No

$95(74.2)$

Contact with home care nurse is exercised

In my home/apartment

In infirmary

$120(93.8)$

$8(6.3)$

Total

$103(100)$

An equal number of respondents answered that visits of the home care nurse should last longer. 80 $(63 \%)$ of the respondents fully agree with the state- ment that they understand the task and role of the home care nurse in the healthcare system, 81 (64\%) that they adhere to the instructions received from the home care nurse, and 99 (79\%) of the respondents completely understand why the home care nurse visits them. So far, 108 (85\%) respondents have not had problems with the home care nurse, and 48 (39\%) have stated that the home care nurse always announces his/her visit (by telephone or preannounced day of the month).

If they want to contact their home care nurse, 92 (72\%) respondents know how (they have home care services's contact phone number), while 7 (5\%) disagree or strongly disagree with this statement. To the majority of the respondents, 107 (84\%), home care nurse gives instructions in a completely understandable way, and if asked to visit someone in poor health in the neighborhood, he/she will always do so, as stated by 77 (64\%) respondents (Table 3 ) .

Respondents had to rate, using grades from 1 to 5 , which traits of the home care nurse are important to them - the most important are kindness and proper appearance, expertise, and slightly less important are treatment counseling and lifestyle counseling.

Only $70(54.6 \%)$ of the respondents answered if the home care nurse explained to them what individual care means, what procedures it involves and how long it takes, and of these, 40 (57\%) fully agree with that statement, while $10(14 \%)$ disagree or do not fully agree. Only $3(3 \%)$ of the respondents answered that they agree or fully agree not to be visited by the home care nurse (Table 4).

There are no significant differences in the attitude of the nurses' work by gender, except that men are more likely to state that the home care nurse always announces his/her visit (by telephone or preannounced day of the month), compared to women.

Respondents living in the city significantly less agree with the statement that there is an accessible book of complaints and praise, that they receive a lot of new information from the home care nurse about their health status and their rights compared to those living in rural areas. Respondents living in the city agree more significantly with the statement that they understand why the home care nurse visits them, that they have not had any problems with the home care nurse so far, they can always contact her, and state that the home care nurse gives them instructions in a completely understandable way. 


\section{Table 2. User attitudes towards home care service (1/3)}

\begin{tabular}{|c|c|c|c|c|c|c|}
\hline & \multicolumn{6}{|c|}{ Number $(\%)$ of respondents } \\
\hline & $\begin{array}{l}\text { Strongly } \\
\text { disagree }\end{array}$ & Disagree & $\begin{array}{l}\text { Can't } \\
\text { decide }\end{array}$ & Agree & $\begin{array}{l}\text { Fully } \\
\text { agree }\end{array}$ & Total \\
\hline $\begin{array}{l}\text { The organization of the home care service is } \\
\text { excellent. }\end{array}$ & 0 & $1(1)$ & $6(5)$ & $38(30)$ & $82(65)$ & $127(100)$ \\
\hline $\begin{array}{c}\text { There is an accessible book of complaints and } \\
\text { praise. }\end{array}$ & $24(21)$ & $9(8)$ & $47(40)$ & $19(16)$ & $18(15)$ & $117(100)$ \\
\hline $\begin{array}{l}\text { I get most of the necessary information about my } \\
\text { health status from the home care nurse. }\end{array}$ & 0 & 0 & $4(3)$ & $28(22)$ & $95(75)$ & $127(100)$ \\
\hline $\begin{array}{c}\text { The home care nurse visits me at least once a } \\
\text { month. }\end{array}$ & $2(2)$ & $3(2)$ & $8(6)$ & 24 (19) & $89(71)$ & $126(100)$ \\
\hline $\begin{array}{l}\text { I receive most of the information from the home } \\
\text { care nurse in relation to the exercise of my rights } \\
\text { (patient rights). }\end{array}$ & 0 & $2(2)$ & $5(4)$ & $30(24)$ & $90(71)$ & $127(100)$ \\
\hline $\begin{array}{l}\text { The home care nurse will inform my physician of } \\
\text { my health issues. }\end{array}$ & $1(1)$ & $1(1)$ & $9(7)$ & $22(18)$ & $91(73)$ & $124(100)$ \\
\hline $\begin{array}{l}\text { Some of my home care nurse's advice is } \\
\text { contradictory to the advice of other healthcare } \\
\text { providers (e.g. general practice physicians ) }\end{array}$ & $59(48)$ & $26(21)$ & $17(14)$ & $7(6)$ & $15(12)$ & $124(100)$ \\
\hline I find the visit of the home care nurse helpful. & 0 & $1(1)$ & $2(2)$ & 19 (15) & 101 (82) & $123(100)$ \\
\hline $\begin{array}{c}\text { I get a lot of new health related information from } \\
\text { the home care nurse. }\end{array}$ & 0 & 0 & $6(5)$ & 34 (27) & $86(68)$ & $126(100)$ \\
\hline $\begin{array}{l}\text { I find that visits from home care nurse should be } \\
\text { more frequent. }\end{array}$ & $13(11)$ & 23 (19) & 40 (33) & 21 (17) & $26(21)$ & $123(100)$ \\
\hline
\end{tabular}

Table 3. User attitudes towards home care service (2/3)

Number (\%) of respondents

\begin{tabular}{|c|c|c|c|c|c|c|}
\hline & $\begin{array}{l}\text { Strongly } \\
\text { disagree }\end{array}$ & Disagree & $\begin{array}{l}\text { Can't } \\
\text { decide }\end{array}$ & Agree & $\begin{array}{l}\text { Fully } \\
\text { agree }\end{array}$ & Total \\
\hline $\begin{array}{c}\text { I think visits of the home care nurse should last } \\
\text { longer. }\end{array}$ & $20(21)$ & $20(21)$ & $25(27)$ & $9(10)$ & $20(21)$ & $94(100)$ \\
\hline $\begin{array}{c}\text { I understand the task and role of the home care } \\
\text { nurse in the healthcare system. }\end{array}$ & 0 & $3(2)$ & $7(6)$ & $36(29)$ & $80(63)$ & $126(100)$ \\
\hline $\begin{array}{l}\text { I adhere to the instructions received from the home } \\
\text { care nurse. }\end{array}$ & $1(1)$ & $2(2)$ & $15(12)$ & $28(22)$ & $81(64)$ & $127(100)$ \\
\hline $\begin{array}{c}\text { I disagree with most of my home care nurse's } \\
\text { advice. }\end{array}$ & $77(62)$ & $23(19)$ & $7(6)$ & $8(6)$ & $9(7)$ & $124(100)$ \\
\hline I understand why the home care nurse visits me. & 0 & 0 & $1(1)$ & $26(21)$ & $99(79)$ & $126(100)$ \\
\hline $\begin{array}{c}\text { So far, I have not had problems with the home care } \\
\text { nurse that visits me. }\end{array}$ & $1(1)$ & $1(1)$ & 0 & $17(13)$ & $108(85)$ & $127(100)$ \\
\hline $\begin{array}{l}\text { Home care nurse always announces his/her visit } \\
\text { (by telephone or pre-announced day of the month) }\end{array}$ & $11(9)$ & $10(8)$ & $22(18)$ & $32(26)$ & 48 (39) & $123(100)$ \\
\hline $\begin{array}{l}\text { If I want to contact my home care nurse I know how } \\
\text { (I have home care services's contact phone number) }\end{array}$ & $4(3)$ & $3(2)$ & $5(4)$ & $23(18)$ & $92(72)$ & 127 (100) \\
\hline $\begin{array}{c}\text { Home care nurse gives instructions in a completely } \\
\text { understandable way. }\end{array}$ & 0 & 0 & $3(2)$ & $17(13)$ & $107(84)$ & 127 (100) \\
\hline $\begin{array}{l}\text { If I ask my home care nurse to visit someone in } \\
\text { poor health in the neighborhood, he/she will do it }\end{array}$ & $1(1)$ & $2(2)$ & 17 (14) & $24(20)$ & 77 (64) & $121(100)$ \\
\hline
\end{tabular}




\section{Table 4. Importance of particular traits of home care nurse, knowledge of practices by home care} nurse, and willingness to be visited by him/her more frequently

\begin{tabular}{|c|c|c|c|c|c|c|}
\hline \multicolumn{7}{|c|}{ Number $(\%)$ of respondents } \\
\hline $\begin{array}{l}\text { Traits of my home care nurse } \\
\text { which are important to care } \\
\text { user (grades from } 1 \text { to } 5 \text { ) }\end{array}$ & 1 & 2 & 3 & 4 & 5 & Total \\
\hline Expertise & 0 & 0 & 0 & $11(9)$ & $116(91)$ & $127(100)$ \\
\hline Kindness & 0 & 0 & 0 & $7(6)$ & $120(94)$ & $127(100)$ \\
\hline Proper appearance & 0 & 0 & 0 & $7(6)$ & $120(94)$ & $127(100)$ \\
\hline Treatment counseling & 0 & 0 & $2(2)$ & $16(13)$ & 109 (86) & $127(100)$ \\
\hline Lifestyle counseling & 0 & 0 & $5(4)$ & $24(20)$ & $94(76)$ & $123(100)$ \\
\hline \multicolumn{7}{|c|}{ For home care users } \\
\hline & $\begin{array}{l}\text { Strongly } \\
\text { disagree }\end{array}$ & Disagree & $\begin{array}{l}\text { Cant`t } \\
\text { decide }\end{array}$ & Agree & Fully agree & Total \\
\hline $\begin{array}{l}\text { My home care nurse explained } \\
\text { to me what individual care } \\
\text { means, what procedures it } \\
\text { involves and how long it takes. }\end{array}$ & $9(13)$ & $1(1)$ & $8(11)$ & $12(17)$ & $40(57)$ & $70(100)$ \\
\hline $\begin{array}{l}\text { I don't want to be visited by } \\
\text { the home care nurse. }\end{array}$ & $93(86)$ & $7(6)$ & $5(5)$ & $1(1)$ & $2(2)$ & $108(100)$ \\
\hline
\end{tabular}

Respondents living in rural areas agree more significantly with the statement that they receive most of the necessary information about their health status from the home care nurse than respondents living in the city.

Regarding the traits that a home care nurse should have, respondents living in rural areas gave a significantly higher rating to expertise, treatment and lifestyle counseling, compared to respondents living in the city.

Respondents living in the city more significantly state that the home care nurse explained to them what individual care means, what procedures it involves, and how long it takes compared to respondents from rural areas (Table 5).

Respondents aged 61 to 80 significantly least agree with the statement that from the home care nurse they receive most of the necessary information about their health status, as well as with the statement that from the home care nurse they receive a lot of new information regarding their health status, compared to younger or older respondents. Respondents up to 60 years of age significantly least agree with the statement that visits by the home care nurse should be more frequent, and that they should last longer. Respondents aged 81 and over significantly more disagree with most of their home care nurse's advice.

Respondents 61 to 80 years of age significantly less agree with the statement that they understand why they are being visited by a home care nurse and that they have not had any problems with them so far, and that if they wish to contact their home care nurse they have significantly less know how than younger or older respondents. Regarding the traits that the home care nurse should have, respondents aged 61-80 find significantly less important treatment counseling (Table 6).

Respondents with higher education agree significantly less with the statement that the home care nurse informs family physicians about their health problems. Respondents who have only completed elementary school significantly less agree that a visit of the home care nurse is beneficial and significantly less understand why the home care nurse visits them. There are significantly fewer problems with the home care nurse by respondents with high school or higher education than those who have only completed elementary school, and they also state 


\begin{tabular}{|c|c|c|c|c|}
\hline & \multicolumn{3}{|c|}{ Median (interquartile range) } & \multirow[t]{2}{*}{$\mathbf{p}^{*}$} \\
\hline & City & $\begin{array}{l}\text { Rural } \\
\text { areas }\end{array}$ & Total & \\
\hline There is an accessible book of complaints and praise. & $2(1-3)$ & $3(3-4)$ & $3(2-4)$ & $<0.001$ \\
\hline $\begin{array}{l}\text { I receive most of the necessary information about my health } \\
\text { status from the home care nurse.. }\end{array}$ & $5(5-5)$ & $4(4-5)$ & $5(4-5)$ & 0.02 \\
\hline $\begin{array}{l}\text { I get most of the information from the home care nurse in relation } \\
\text { to the exercise of my rights (patient rights). }\end{array}$ & $5(5-5)$ & $4(4-5)$ & $5(4-5)$ & 0.003 \\
\hline $\begin{array}{l}\text { I receive a lot of new health related information from the home } \\
\text { care nurse. }\end{array}$ & $5(5-5)$ & $4(4-5)$ & $5(4-5)$ & 0.03 \\
\hline I understand why the home care nurse visits me. & $5(5-5)$ & $4(4-5)$ & $5(5-5)$ & 0.04 \\
\hline $\begin{array}{c}\text { So far, I have not had any problems with the visiting home care } \\
\text { nurse. }\end{array}$ & $5(5-5)$ & $4(4-5)$ & $5(5-5)$ & $<0.001$ \\
\hline $\begin{array}{l}\text { If I want to contact my home care nurse I know how (I have the } \\
\text { contact phone number of the home care service) }\end{array}$ & $5(5-5)$ & $4(4-5)$ & $5(4-5)$ & 0.04 \\
\hline $\begin{array}{c}\text { The home care nurse gives me directions in a completely } \\
\text { understandable way. }\end{array}$ & $5(5-5)$ & $4(4-5)$ & $5(5-5)$ & 0.002 \\
\hline Traits: Expertise & $4(4-5)$ & $5(5-5)$ & $5(5-5)$ & 0.03 \\
\hline Treatment counseling & $4(4-5)$ & $5(5-5)$ & $5(5-5)$ & 0.002 \\
\hline Lifestyle counseling & $4(4-5)$ & $5(4-5)$ & $5(5-5)$ & 0.02 \\
\hline $\begin{array}{l}\text { My home care nurse explained to me what certain care means. } \\
\text { which procedures it involves and how long it takes }\end{array}$ & $5(4-5)$ & $4(3-5)$ & $5(3-5)$ & 0.005 \\
\hline
\end{tabular}

\section{Table 6. Assessment of attitudes about the work of the home care service by age}

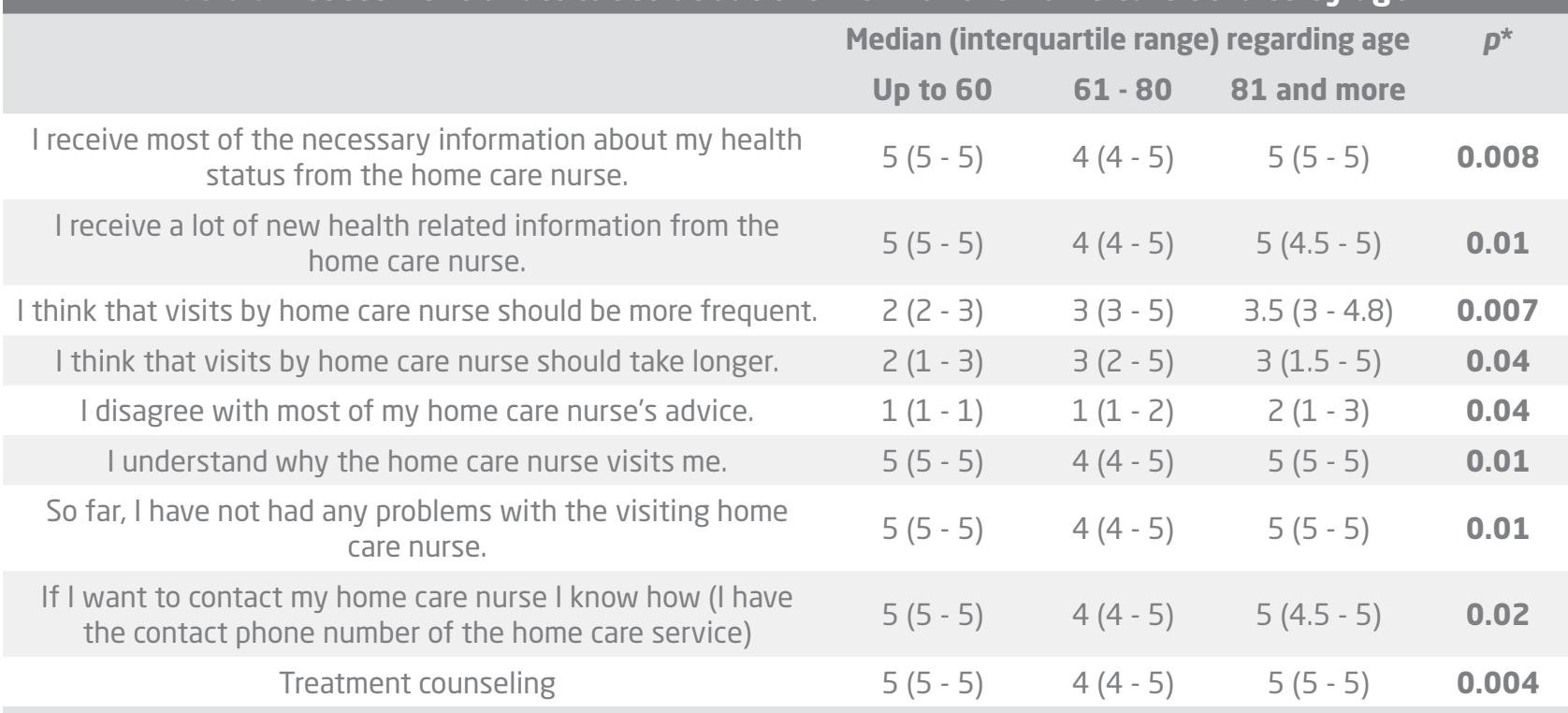


that the home care nurse gives them instructions in a completely understandable way unlike respondents who have only completed elementary school.

Considering the traits that the home care nurse must have, treatment counseling and lifestyle counseling are significantly less important for the respondents who have only completed elementary school (Table 8).

With respect to the employment status, in most statements there are no significant differences between the respondents who are employed and those who are not, except for three statements. It is significantly less important for employed respondents for visits by the home care nurse to last longer, while treatment and lifestyle counseling are significantly less important for those who do not work.

If there were problems with the home care nurse, 52 $(44.1 \%)$ of the respondents would report it to their family physician, $14(11.9 \%)$ to the head nurse of the health center, 4 (3.4\%) would report to the other nurse (in infirmary, home care), while 47 (40.6\%) would not report them to anyone (Graph 1 ).

The respondents were able to indicate what they wanted to change in the functioning of the home care service, which they believed would improve the work of the home care nurse. The most common suggestions are more frequent visits, then the introduction of an afternoon shift for employed respondents, and that the number of home care nurses should be increased so that each home care nurse could stay longer with the respondents.

\section{Table 7. Assessment of attitudes about the work of the home care service in relation to the level of education

\begin{tabular}{|ccccc} 
& \multicolumn{1}{c}{$\begin{array}{c}\text { Median (interquartile range) by } \\
\text { educational level } \\
\text { elementary } \\
\text { School }\end{array}$} & $\begin{array}{c}\text { High school } \\
\text { education }\end{array}$ & $\begin{array}{c}\text { Bacc./ masters } \\
\text { degree }\end{array}$ \\
\hline $\begin{array}{c}\text { The home care nurse will inform my general practice } \\
\text { physician of my health issues. }\end{array}$ & $5(4-5)$ & $5(5-5)$ & $4(3-5)$ & $\mathbf{0 . 0 1}$ \\
\hline $\begin{array}{c}\text { I consider visits by the home care nurse useful. } \\
\text { I understand why the home care nurse visits me. }\end{array}$ & $4(4-5)$ & $5(5-5)$ & $5(5-5)$ & $\mathbf{0 . 0 3}$ \\
\hline $\begin{array}{c}\text { So far. I have not had any problems with the home care nurse. } \\
\text { The home care nurse gives me instructions in a completely } \\
\text { understandable way. }\end{array}$ & $4(4-5)$ & $5(5-5)$ & $5(5-5)$ & $\mathbf{0 . 0 0 1}$ \\
\hline Treatment counseling & $4(4-5)$ & $5(5-5)$ & $5(5-5)$ & $\mathbf{0 . 0 0 1}$ \\
\hline Lifestyle counseling & $4(4-5)$ & $5(5-5)$ & $5(5-5)$ & $\mathbf{0 . 0 1}$ \\
\hline
\end{tabular}

*Kruskal Wallis test

Table 8. Assessment of attitudes about the work of the home care service in relation to work status

\begin{tabular}{|c|c|c|c|c|}
\hline & \multicolumn{3}{|c|}{$\begin{array}{c}\text { Median (interquartile range) by } \\
\text { employment }\end{array}$} & \multirow[t]{2}{*}{$\boldsymbol{p}^{\star}$} \\
\hline & Working & Not working & Total & \\
\hline I think that visits of the home care nurse should take longer. & $2(1-3)$ & $3(2-5)$ & $3(2-4)$ & 0.007 \\
\hline Treatment counseling & $5(5-5)$ & $4(4-5)$ & $5(5-5)$ & 0.01 \\
\hline Lifestyle counseling & $5(5-5)$ & $4(4-5)$ & $5(5-5)$ & 0.03 \\
\hline
\end{tabular}




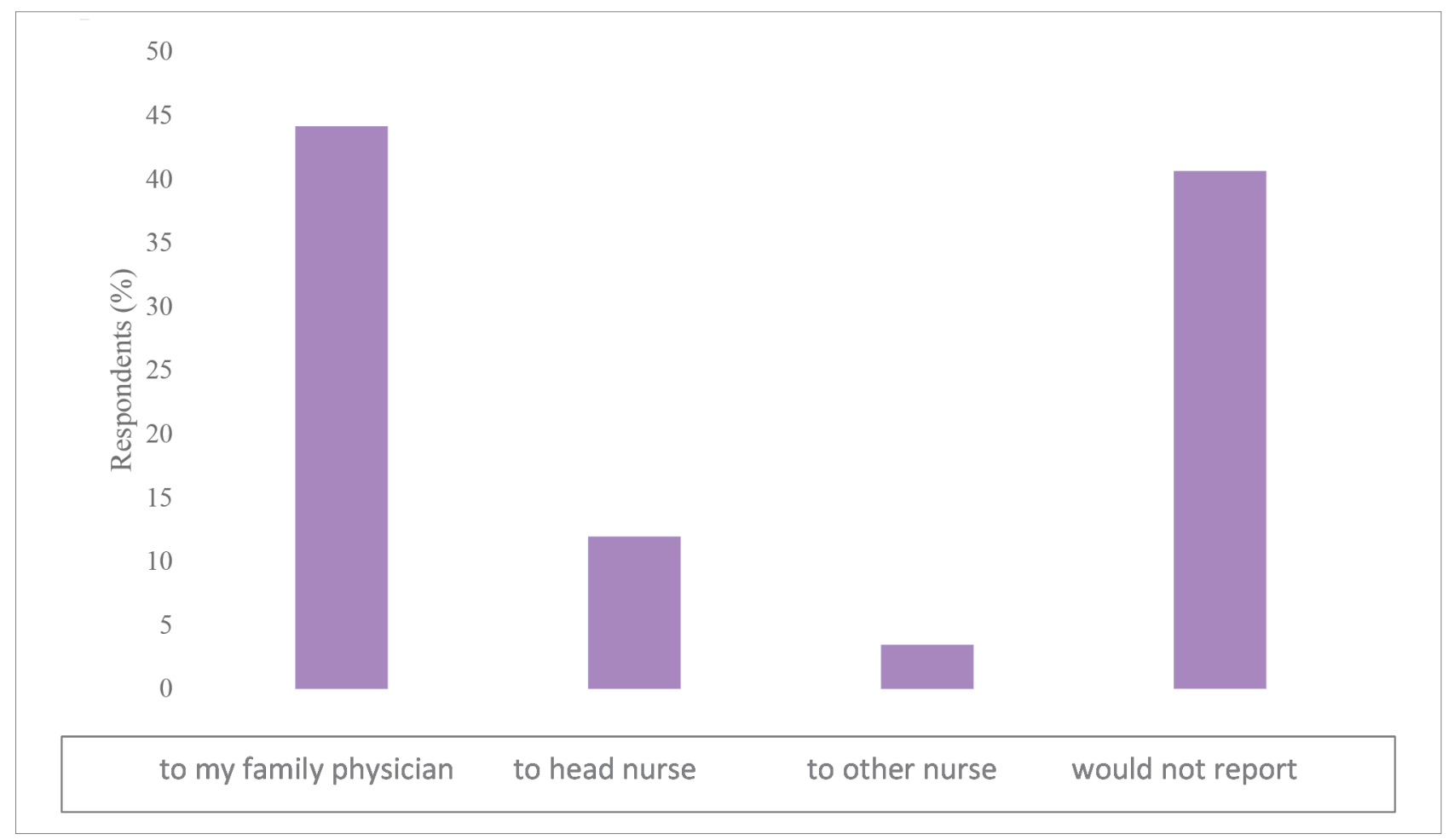

Graph 1. Distribution of respondents according to whom they would report the home care nurse if there were problems

\section{Discussion}

Home health care covers the care of people throughout their lifespan. Customer satisfaction is important for improving home health care itself. The majority of users in the survey, 120 (93.8\%), have contact with a home care nurse at their home or apartment. Therefore, it can be concluded that these are mostly elderly and chronic patients who have difficulty moving and cannot get in touch with the home care nurse in the infirmary. According to the statistics of the Croatian Institute of Public Health, the largest number of visits (761.308) are to chronic patients, with the purpose of giving instructions and demonstrating certain selfcontrol procedures and preventing complications of the underlying chronic illness, and conducting therapeutic procedures in barely mobile and immobile persons, in agreement with a selected physician (12). A quarter of the users, or $33(25.8 \%)$ of the respondents, are also visited by a home care professional. These are users the home care nurse needs to educate on what individual care means, how long it takes, and what care provided by the home care nurse includes, what the patient rights are, and the like. Only 70 (54.6\%) of the respondents answered whether the home care nurse explained to them what individual care meant. Respondents living in the city more significantly state that the home care nurse explained to them what individual care means, what procedures it involves, and how long it takes compared to rural respondents. Respondents living in the city significantly less agree with the statement that there is an accessible book of complaints and praise, that they receive a lot of new information from the home care nurse about their health status and their rights compared to rural respondents. Similar results are shown in llakovac research, in which respondents from the city are less satisfied with the work of health workers (13). Respondents from the city significantly more agree with the statements that they understand why the home care nurse visits them, that they have not had problems with the home care nurse so far, that they can always contact him/her, and state that the home care nurse gives them instructions in a completely understandable way. Respondents living in rural areas agree much more with the statement that they receive most 
of the necessary information about their health status from the home care nurse than respondents living in the city. Considering the characteristics that a home care nurse should have, the rural respondents gave a higher rating to expertise and treatment counseling. These results illustrate the educational role of the home care nurse in rural areas.

The majority, or $82(65 \%)$ of the users surveyed, agree that the organization of the home care service is excellent. However, there remains a number of users who believe that better home care service should be worked on. Better organization would certainly be aided by the pre-announcement of the visit by phone or the prior agreement with the user on the exact date the next visit is planned, which is confirmed by the fact that only 48 (39\%) of the respondents state that the nurse always announces their visit. Men more significantly state that the home care nurse always announces his/her visit, compared to women. Respondents up to 60 years of age significantly least agree with the statement that home care nurse visits should be more frequent and last longer. It is significantly less important for employed respondents that visits of the home care nurse take longer, which can be explained by the fact that users do not have time for long visits and talks with the home care nurse.

$95(75 \%)$ of the respondents state that they receive most of the necessary information about their health status from the home care nurse. The home care nurse visits most of the respondents $89(71 \%)$ once a month, although patients who are also cared for by home care professional should be visited by home care nurse at least twice a month. $80(63 \%)$ of the respondents completely agree with the statement that they understand the task and role of the home care nurse in the healthcare system, $81(64 \%)$ that they adhere to the instructions received from the home care nurse, and 99 $(79 \%)$ of the respondents fully understand why they are visited by the home care nurse. 101 (82\%) of the respondents fully agree that the visit of the home care nurse is beneficial. $86(68 \%)$ of the respondents completely agree with the statement that from the home care nurse they receive a lot of new information related to their health status. The respondents aged 61 to 80 years, compared to younger or older respondents, significantly least agree with the statement that the home care nurse provides most of the necessary information about their health status, as well as with the statement that the home care nurse provides a lot of new information regarding their health status. Respondents aged
81 years and over disagree significantly with most of their home care nurse's advice. This is an interesting piece of information that can be related to the fact that younger respondents also use other sources of information (they use the Internet), that is, they do not receive all the necessary information about their health status only from the home care nurse. The confirmation of this is a study by Walkerai et al. where younger respondents were more satisfied with health care as opposed to the older ones (14). Older respondents also have a problem with cognitive deficits so this can explain the fact that the information they received from the home care nurse is not clear enough. In the Novakovic survey from 2017, similar results were obtained, patients often stated that they had received too little information about their illness, that the information was incomprehensible and unclear, that their problems were not taken seriously, that the vocabulary used was incomprehensible (15). A study conducted in Karlovac found that older people rated nurses' attitudes and care lower (16).

Respondents who completed only elementary school significantly less agree that a visit of the home care nurse is beneficial and significantly less understand why the home care nurse visits them. Similar research results from llakovac showed that respondents with un/completed elementary school were significantly more dissatisfied with the rapport and care of the home care nurses (13). The cause can be interpreted in that the home care nurses do not convey certain information in a sufficiently understandable way, given the literacy level of the respondents. In the Novaković survey from 2017, which examines patient satisfaction with the work of nurses in primary health care, there is a significantly lower agreement with the statements in the area of patient satisfaction with the amount of information they receive from a nurse in a group of school respondents, while a higher rating with regard to satisfaction is given by respondents with completed elementary education and respondents with a university degree (15).

Respondents find kindness, proper appearance and expertise as the most important, and as slightly less important - the treatment counseling and lifestyle counseling. Similar results are obtained by Novakovic, where the user does not describe the nurse's expertise and experience as important, but rather observes decency, confidence, careful listening to the patient, which can dispel fear and anxiety, gain patient confidence and facilitate good collaboration (15). Solayappan, Jayakrishan, and Velmani, in 2011, have come up with the factors that 
make up the biggest gap between the expected and perceived quality of patient health services, such as: proper employee appearance, lack of interest in problem solving, service communication, fulfilling the promise of a healthcare professional, insufficient knowledge to answer patient's query (17). Researchers have also found that the kindness and respect of healthcare professionals most influences user satisfaction, with communication and explanation being the second most important form of satisfaction (18). This is an interesting piece of information for nurses that could enhance the work of the home care service and customer satisfaction. The most common suggestions of what would improve home care service are more frequent visits, then the introduction of an afternoon shift for employed respondents, and that the number of home care nurses should be increased, allowing each home care nurse to stay longer with the respondent. If there were problems with the home care nurse, 52 (44.1\%) respondents would report them to their family physician.

\section{Conclusion}

Based on the conducted research and the results obtained, the following conclusions can be drawn:

- more than half of the respondents were satisfied with the organization of the home care service;

- almost all respondents receive most of the necessary information about their health status from the home care service;

- the majority of the respondents believe that the home care nurse visits them often enough;

- the most common suggestions for improving home care service are more frequent visits, then introducing an afternoon shift for employed respondents, and that the number of home care nurses should be increased, allowing each home care nurse to stay longer with the respondent.

Hypothesis 1 is confirmed - home care service beneficiaries have a positive attitude towards home care service.

Hypothesis 2 is confirmed - beneficiaries receive sufficient information from the home care nurse about their health status.

\section{References}

1. Hrvatsko društvo obiteljskih doktora. Patronažna služba i obiteljski liječnik. 2011. Available from: http:// www.hdod.net/rad_drustva/Patronazna_i_doktor.pdf Accessed: 15.05.2019. Croatian.

2. Plan i program mjera zdravstvene zaštite iz obveznog zdravstvenog osiguranja. NN 126/2006;2279.

3. Županić M. Organizacija, obrazovanje i kompetencije patronažnih medicinskih sestara. Hrvatski časopis za javno zdravstvo. 2013;9(33):5-15.

4. Mojsović Z. Zdravstvena njega u zajednici. Zagreb: Visoka zdravstvena škola; 2005. Croatian.

5. Županić M. Strategije razvoja sestrinstva u zajednici. U: Zbornik radova Konferencije Zdravstvenog veleučilišta „Perspektive individualnog i profesionalnog razvoja u sestrinstvu". Opatija: Zdravstveno veleučilište; 2008. Croatian.

6. Nakić D. Patronažne sestre u provedbi nacionalnih programa ranog otkrivanja raka. Zagreb: Hrvatski zavod za javno zdravstvo; 2015. Croatian.

7. Hanžek K. Otpusno pismo zdravstvene njege kao oblik suradnje bolničkih i patronažnih sestara [diplomski rad]. Zagreb: Sveučilište u Zagrebu, Medicinski fakultet Zagreb; 2015. Croatian.

8. Pravila i opći uvjeti ugovaranja PZZ. Zagreb: Hrvatski zavod za zdravstveno osiguranje; 2006. Croatian.

9. Narodne novine. Pravilnik o uvjetima i načinu ostvarivanja prava iz osnovnog zdravstvenog osiguranja za provođenje zdravstvene njege u kući NN 76/02. Zagreb: Narodne novine d.d. 2002. Croatian.

10. Narodne novine. Zakon o sestrinstvu NN 121/03. Zagreb: Narodne novine d.d. 2003. Croatian.

11. Carr-Hill R. The measurement of patient satisfaction. J Public Health Med. 1992;14(3):236-49.

12. Hrvatski zavod za javno zdravstvo. Hrvatski zdravstveno-statistički ljetopis za 2014. godinu. Zagreb: Hrvatski zavod za javno zdravstvo; 2014. Croatian.

13. Ilakovac I. Zadovoljstvo korisnika zdravstvenom zaštitom u Lječilištu Bizovačke toplice [diplomski rad]. Osijek: Sveučilište Josipa Jurja Strossmayera u Osijeku, Medicinski fakultet Osijek; 2017. Croatian.

14. Walker MS, Ristvedt SL, Haughey BH. Patient care in multidisciplinary clinics: does attention to psychosocial needs predict patient satisfaction. Scand J Prim Health Care. 2007;25(4):226-31.

15. Novaković j. Zadovoljstvo pacijenata radom medicinskih sestara/tehničara u primarnoj zdravstvenoj zaštiti [diplomski rad]. Osijek: Sveučilište Josipa Jurja Strossmayera u Osijeku, Medicinski fakultet Osijek; 2017. Croatian.

16. Cvitanović $H$, Jančić $E$, Knežević $E$, Kuljanac I. Zadovoljstvo bolesnika kvalitetom zdravstvene zaštite u dermatološkoj poliklinici Karlovac. Medicina Fluminesis. 2011;47(1):82-90. Croatian.

17. Gutić D. Upravljanje zadovoljstvom i odnosima s pacijentima. Osijek: Grafika; 2015. Croatian.

18. Ali-Abri, Al-Balushi A. Patient satisfaction Survey as Tool Towards Quality Improvement. Oman Med J. 2014;29(1):3-7. 


\section{MIŠLJENJA KORISNIKA USLUGA O NAČINU RADA PATRONAŽNE SLUŽBE}

\section{Sažetak}

Cilj. Ispitati zadovoljstvo korisnika patronažne službe, ispitati dobivaju li korisnici dovoljno informacija od patronažne sestre o svojem zdravstvenom stanju, smatraju li da ih patronažna sestra učestalo posjećuje te što bi promijenili u radu patronažne službe.

Metode. Istraživanje je provedeno kao presječna studija. Ukupno je sudjelovalo 128 korisnika patronažne službe Doma zdravlja Sisak s pomoću anketnog upitnika koji se sastoji od 25 pitanja. Odgovori se definiraju primjenom Likertove skale procjena.

Rezultati. Da je organiziranost patronažne službe izvrsna slaže se 82 (65 \%) ispitanika, a da od patronažne sestre dobije većinu potrebnih informacija o svojem zdravstvenom stanju navodi 95 (75\%) ispitanika. Patronažna sestra većinu ispitanika posjećuje, njih 89 (71 \%) jednom mjesečno. Najčešći su prijedlozi za poboljšanje funkcioniranja patronažne službe češći posjeti, zatim uvođenje poslijepodnevne smjene za ispitanike koji su u radnom odnosu te da bi se trebao povećati broj patronažnih sestara, čime bi svaka patronažna sestra mogla dulje ostati kod ispitanika.

Zaključak. Korisnici patronažne službe imaju pozitive stavove prema patronažnoj službi i dobivaju dovoljno informacija od patronažne sestre o svojem zdravstvenom stanju 